\title{
SRD5A2 Gene
}

National Cancer Institute

\section{Source}

National Cancer Institute. SRD5A2 Gene. NCI Thesaurus. Code C18502.

This gene is involved in androgen metabolism and sexual differentiation. 